\title{
Artelogie
}

Recherche sur les arts, le patrimoine et la littérature de l'Amérique latine

1 | 2011

Brésil, questions sur le modernisme

\section{Um modernista em ação na America Latina: a trajetória do gravador brasileiro Lívio Abramo no Paraguai}

\section{Margarida Nepomuceno}

\section{(2) OpenEdition}

\section{Journals}

\section{Edição electrónica}

URL: https://journals.openedition.org/artelogie/8608

DOI: 10.4000/artelogie.8608

ISSN: 2115-6395

\section{Editora}

Association ESCAL

Refêrencia eletrónica

Margarida Nepomuceno, «Um modernista em ação na America Latina: a trajetória do gravador brasileiro Lívio Abramo no Paraguai», Artelogie [Online], 1 | 2011, posto online no dia 01 março 2011, consultado o 07 janeiro 2022. URL: http://journals.openedition.org/artelogie/8608; DOI: https:// doi.org/10.4000/artelogie.8608

Este documento foi criado de forma automática no dia 7 janeiro 2022.

Association ESCAL 


\title{
Um modernista em ação na America Latina: a trajetória do gravador brasileiro Lívio Abramo no Paraguai
}

\author{
Margarida Nepomuceno
}

\section{Introdução}

1 Por los caminos de la Cultura y del Arte se estrechen cada vez máslos lazos de amistad y comprensión entre los pueblos del Paraguay y del Brasil².

2 A importância das relações culturais entre as nações latino-americanas é cada vez mais reconhecida pelos estudiosos das relações internacionais como um instrumento essencial de política externa, muito embora as pesquisas desenvolvidas nessa área específica, sejam ainda embrionárias.

No Brasil, apesar da quantidade de documentação diplomática arquivada nos centros de documentação histórica do Ministério das Relações Exteriores, em Brasília, e no Palácio do Itamaraty, no Rio de Janeiro, são recentes os estudos publicados sobre o tema, fato que provavelmente seja explicado pela incipiente formação dos cursos acadêmicos voltados para o campo das Relações Internacionais. Destacaria duas publicações de relevância para o estudo do tema: O Itamaraty na Cultura Brasileira, organizado por Alberto da Costa e Silva, e Diplomacia Cultural: seu papel na Política Externa Brasileira, de Edgard Telles Ribeiro, ambos embaixadores brasileiros, com passagens na área das relações culturais do Ministério das Relações Exteriores. ${ }^{3}$ Em relação à América Latina, o Brasil empreendeu algumas ações culturais, desde o inicio do século passado, que demonstram a preocupação do país em estabelecer uma aproximação com os países vizinhos.No presente estudo, destacamos o programa denominado de Missão Cultural Brasileira, considerada uma das mais antigas iniciativas da política externa do Brasil de ação continuada: no Uruguai existe há 70 anos, no Paraguai há 66 e em Buenos Aires há 56 anos. ${ }^{4}$ 
4 No Paraguai, a Missão Cultural Brasileira (MCB) tem início com a implantação de convênios, sem uma denominação específica, pois fazia parte dos demais acordos que versavam sobre interesses diversos entre os governos. Entretanto, a chegada de Lívio Abramo naquele país, como coordenador das ações artísticas, ajudou a definir o perfil cultural da MCB. Ao chegar a Assunção, em 1962, a ditadura de Alfredo Stroessner já havia se instalado há 8 anos no país. Nessa mesma época, no Brasil, a instabilidade política já mostrava sinais dos tempos difíceis que se aproximavam com a implantação do regime militar. Lívio Abramo permaneceu no Paraguai por trinta anos, de 1962 até a sua morte, em 1992, e marcou a sua atuação não somente como orientador dos talleres de $a_{r t e}$, como também, como articulador cultural, integrando-se na comunidade local e contribuindo com suas propostas para o desenvolvimento do meio artístico e cultural da cidade. Um das consequências desse trabalho foi a incorporação, pelas escolas locais, do método pedagógico fundado na libre expresión por el arte, ${ }^{6}$ utilizado pela Escolinha de Arte, coordenada por Lívio Abramo.

5 No livro A consolidação da ditadura de Stroessner, 1954-1963, ${ }^{7}$ a historiadora Ceres Moraes defende que a presença do Brasil no Paraguai, especialmente nesse período, foi determinante para a solidificação da ditadura militar. Para ela, além da ajuda econômica, o Brasil teria centrado sua política colaboracionista na ajuda militar, sobretudo no combate a guerrilha, como também nas ações da diplomacia brasileira. Mais adiante, a autora atribui o papel da Missão Cultural Brasileira no Paraguai como sendo um dos pilares da política colaboracionista, uma vez que por meio das ações culturais o governo brasileiro teria criado, no interior da sociedade paraguaia, condições para uma mudança de mentalidade a respeito das vantagens das políticas de aproximação com o Brasil. A Missão teria atuado como uma espécie de frente de modernização e quebra de resistência de antigas mágoas históricas. Para a historiadora, a Missão Cultural Brasileira, “ ainda que não fosse seu objetivo, contribuiu de alguma forma para prestigiar a ditadura".

6 As ações prolongadas da Missão Cultural no Paraguai, durante mais de 60 anos, não podem ser definidas como meras generosidades diplomáticas ou casualidades políticas, ou ainda, como trocas gratuitas e espontâneas de experiências culturais no âmbito das relações internacionais. Ao contrário, desde o início, foram ações de concordâncias entre os Estados, regidas por convênios e acordos oficiais e que estabeleceram, entre os países, uma consistente diplomacia cultural. Não há, portanto, como analisar separadamente as ações culturais das ações políticas de Estado, cuja síntese originou a própria expressão diplomacia cultural. É fundamental, entretanto, distingui-las, evidenciando cada um dos seus domínios, para não reduzir a importância da Missão Cultural Brasileira no Paraguai no mesmo leito lamacento das ações colaboracionistas entre ditaduras, que existiram, infelizmente, como bem se pode comprovar com o trabalho de Paz, González e Palau. ${ }^{9}$ 
Exposição dos trabalhos da mostra em comemoração aos 10 anos da Escolinha de Arte.Lívio Abramo e a artista paraguaia Olga Blinder, $1^{\text {a }}$ da esq. p/dir.Arquivo da Escolinha de Arte. Assunção, 1969

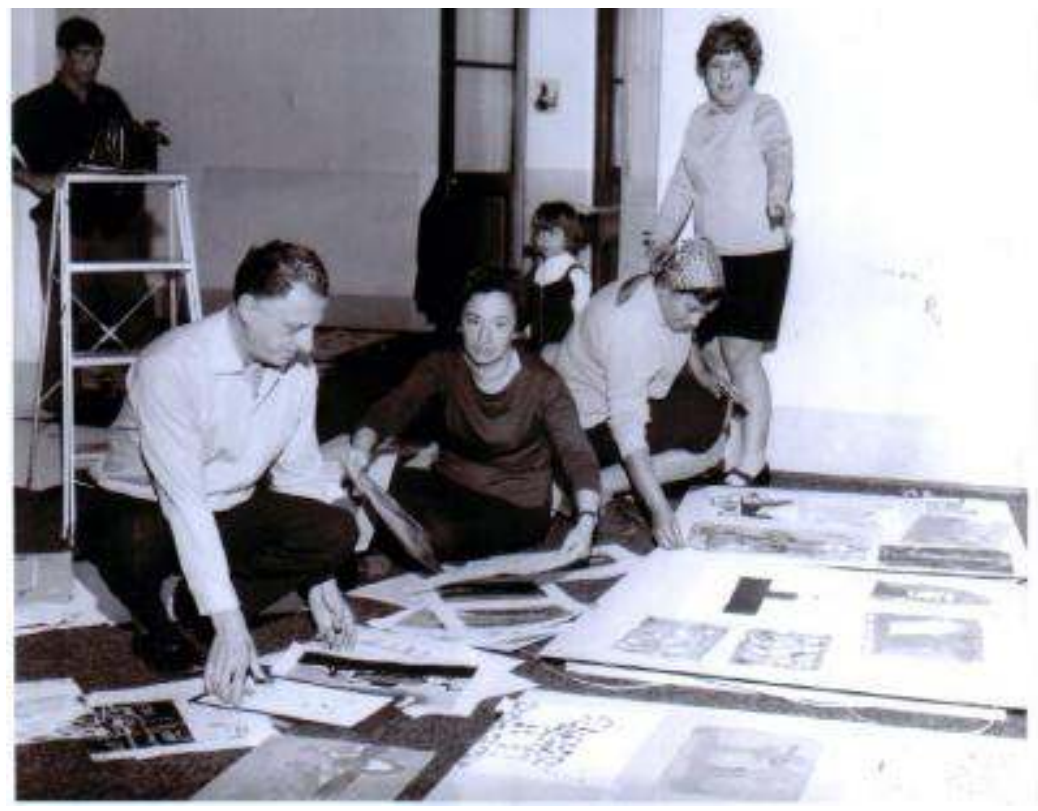

\section{Herança do moderno paulista}

Uma das preocupações de Lívio Abramo foi com a defesa do patrimônio históricocultural das antigas missões jesuíticas. Seu empenho pessoal na criação de uma política de preservação desse patrimônio, junto a membros da Embaixada Brasileira e intelectuais do país resultou, em 1967, na criação do Instituto do Patrimônio Histórico e Artístico Nacional (IPHAN). Preocupação que se estendeu mesmo depois da criação da instituição, segundo depoimento da restauradora paraguaia Estela Cubero, a primeira diretora do IPHAN. Lívio e uma equipe de profissionais visitavam constantemente igrejas e povoados, os pueblos, das antigas reduções jesuíticas e franciscanas, empreendendo verdadeiras campanhas educativas para registrar o patrimônio local, conscientizar e agregar os esforços da população para a defesa dos bens culturais. ${ }^{10}$

Outro importante eixo do seu trabalho foi a integração entre as comunidades artísticas dos dois países. Lívio Abramo realizou em Assunção inúmeras exposições de artistas paraguaios e brasileiros, criando um intenso fluxo entre Brasil e Paraguai. Acervos particulares e de diferentes museus brasileiros foram levados até a capital paraguaia. Um ano após a sua morte, o crítico Miguel Ángel Fernandéz reuniu no livro Artes y Artistas del Paraguay, dezenas de textos escritos por Lívio, a partir do ano de 1966, para essas exposições. Essa coletânea é parte considerável do que o artista produziu durante a sua vida, e revela uma intenção de formar um campo específico para a produção e apreciação da arte. São críticas, em sua maioria, de teor educativo, e reveladoras de sentido social e político que Lívio Abramo imprimia em sua "missão" cultural.

9 Ao visitar Assunção pela primeira vez em 1956, seis anos antes de mudar-se definitivamente para lá, o brasileiro encontrou uma comunidade artística empenhada na realização de seus propósitos de renovação nas artes. O Paraguai estava assolado por uma economia debilitada, resultado de períodos sucessivos de guerras e golpes 
políticos, e pela recente e violenta ascensão do general Alfredo Stroessner ao poder (1954-1989), e no campo da arte, segundo a escritora hispano-paraguaia Josefina Plá, até a metade do século XX havia uma situação estacionária entre os poucos artistas com presença no Paraguai. Situação que vai alterar-se, a partir da criação do Grupo Arte Nuevo, em 1953, quando tem inicio um tímido processo de renovação nas artes com preocupação centrada em acompanhar os passos das vanguardas internacionais. Tímido, pois o processo de modernização artística paraguaio ocorreu dentro de um cenário político tensionado pelo ideário do regime militar. É extremamente valorizado entre críticos e artistas contemporâneos de Lívio Abramo o empenho do artista brasileiro para alavancar esse processo de renovação tão almejada pela comunidade artística daquele país. Todos os depoimentos colhidos por essa pesquisadora durante as viagens ao Paraguai confirmam essa importância. Lívio interfere ativamente nesse processo levando experiências de uma realidade cultural vivida durante 30 anos no circuito das artes no Brasil, especialmente em São Paulo, onde participou das primeiras bienais e salões de arte. Lívio estava entre os mais importantes artistas gravadores modernos, ganhou prêmios e desfrutou do convívio com críticos de arte, políticos e jornalistas

Lívio Abramo ( ao centro) e Dora Guimarães na preparação da sala daArte Religiosa das Antigas Missões do Paraguai, na VI Bienal Internacional de São Paulo, 1961

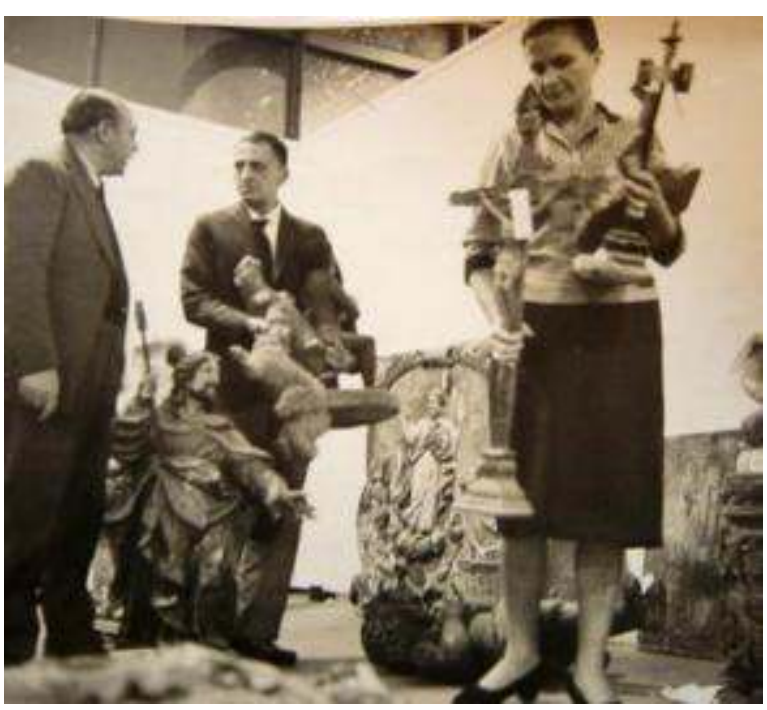

Em 1961, Lívio Abramo foi um dos delegados de uma das salas especiais da VI Bienal Internacional de São Paulo quando trouxe para o Brasil, a convite de Mario Pedrosa, a Arte Religiosa das Antigas Missões do Paraguai chamando a atenção para a pouco valorizada cultura das reduções jesuíticas instaladas naquele país nos séculos 17 e 18 . Essa experiência valeu-lhe, logo em seguida, ao mudar-se para lá, credibilidade e respeito do meio artístico paraguaio.Portanto, o papel de Lívio Abramo naquele país, ultrapassou a precípua incumbência de criar uma escola de gravura e ministrar aulas de História da Arte. $O$ artista brasileiro formou gerações de artistas, especialmente gravadores, bem como ajudou na formação de docentes, que atuam até hoje em instituições de ensino, além de ter colaborado para desenvolver o campo da crítica de arte. 


\section{Lívio Abramo e a Diplomacia Cultural}

11 A compreensão da obra de Lívio Abramo naquele país não se completa se não forem considerados alguns fatores que vão além da dimensão artístico-social de sua obra. Importantes fatores, da ordem das relações políticas internacionais, responsáveis pela proximidade dos dois países, trazem para o campo da investigação substanciais elementos para entendermos a atuação do artista naquele cenário e o relevante papel desempenhado pela Missão Cultural Brasileira no Paraguai. A história da construção da diplomacia cultural entre Brasil e Paraguai, antes mesmo da vigência dos regimes militares, ainda está por ser escrita. Existem algumas reflexões sobre as ações culturais do Itamaraty, produzidas pelo Instituto Rio Branco, mas nada específico sobre o papel desempenhado pelas Missões Culturais Brasileiras no Paraguai ou em demais países da America Latina onde o Brasil desenvolveu semelhantes programas culturais. A década de 50 marca o início mais acentuado do restabelecimento das relações entre Brasil e Paraguai. Após um período de visível afastamento, historicamente compreendido desde finais do século XIX até o primeiro quarto do último século, o Paraguai distanciou-se do Brasil e permaneceu na esfera de influência da Argentina, por inúmeras razões dentre as quais estariam os condicionantes geográficos. Sem saída para o mar o Paraguai submeteu-se a política de Buenos Aires, que durante décadas decidiu sobre as prioridades econômicas do país do Rio de la Plata. Somente a partir dos anos 40, o Paraguai busca aproximar-se do Brasil envidando esforços para sair da esfera hegemônica argentina e criar alternativas para exercer com autonomia, a sua própria política econômica. Para Ronaldo Alexandre do Amaral e Silva, pesquisador das relações entre Brasil e Paraguai ${ }^{11}$, a visita de Getulio Vargas à Assunção em 1941, criaria as bases para a mudança dessa situação. Os vários acordos assinados naquele ano tiraram do papel as simples intenções de Estado e colocaram o Brasil diante do desafio de executar ações colaboracionistas no Paraguai nos anos que se seguiram. Um desses acordos foi a concretização da saída para o Leste, antigo sonho acalentado pelo Paraguai desde o século anterior, por meio da realização de um conjunto de obras de infra estrutura para prover o Paraguai de uma saída direta para o Atlântico, por meio dos portos brasileiros.

12 No campo cultural, é importante destacar que antes do Brasil empenhar-se em promover os acordos de maior vulto econômico com o Paraguai, várias ações de intercâmbio e de cooperação cultural já estavam sendo realizadas. Em 24 de junho de 1939, em meio a um acordo que estabelecia as bases para intercâmbios de variados interesses entre os governos, aparece registrada pela primeira vez a intenção do Brasil em estabelecer com o Paraguai um acordo de cooperação cultural.

13 Esse ato institucional só teria desdobramentos dois anos mais tarde, em 1941, quando foram concluídas e assinadas pelos dois países, ações específicas de mútua colaboração nas áreas da cultura e das ciências, por meio do decreto lei 7.712. Assinado no Rio de Janeiro em 24 de agosto de 1941, pelo presidente Getulio Vargas, e ratificado pelo ministro de Estado da Educação do Paraguai e por seu presidente, Higino Morígino, o decreto em questão estabeleceu a realização de convênios de intercâmbios, especialmente na área da educação, representando o início de um vasto programa cultural, que ficaria conhecido posteriormente como Missão Cultural Brasileira.

14 Ao lado da Missão Cultural Brasileira de Montevidéu, a primeira criada na America Latina, a Missão no Paraguai (MCB), constituiu o mais antigo programa implantado na 
região pelo Departamento Cultural do Ministério das Relações Exteriores (Itamaraty) do Brasil. ${ }^{12}$ Oficialmente foi criada somente em 1952, mas desde a década de 40 , como já se mencionou, as ações de intercâmbio já ocorriam e eram organizadas diretamente entre os governos, por meio das embaixadas.Desse período em diante verificou-se um crescimento cada vez maior da presença brasileira na vida cultural do Paraguai. As atividades da MCB foram muito além da organização de cursos de português e literatura inicialmente planejados. Seus desdobramentos redimensionaram o perfil inicial da MCB que se constituiu, especialmente a partir dos anos 50, em um programa da diplomacia cultural amplo e diversificado, de estreita penetração na comunidade cultural do país.

No final da década de 50 e início dos 60 , várias instituições de ensino já haviam sido criadas no Paraguai, como resultado das ações integradas entre os dois países. Dentre as mais importantes se encontram a Escola Brasil, destinada à formação básica de alunos $\mathrm{e}$ o Colégio Experimental Paraguai-Brasil, fundado em sete de setembro de 1964. Este último, teve o programa pedagógico inspirado nos colégios experimentais que haviam sido criados no Rio de Janeiro, na década de 50. Essas unidades possuíam bibliotecas cujos acervos eram, em boa parte, doados pelo governo brasileiro, que traduzia livros do espanhol para o português e os enviava para o Paraguai.A MCB no Paraguai foi um programa que envolveu nomes respeitados do meio cultural e educacional do Brasil. Alguns tiveram um comprometimento maior, fixando residência no Paraguai. Foi o caso de muitos professores da Missão e, em especial, para o presente estudo, do artista gravador Lívio Abramo. Outros permaneceram no país somente algumas semanas, ou dias apenas, tempo suficiente para colaborar com alguma iniciativa. Casos, por exemplo, de Augusto Rodriguez, artista pernambucano, criador da Escolinha de Arte do Paraguai , em 1959, como já se mencionou acima. Boa parte dos professores que serviram a MCB permaneceram no país por dois anos, tempo do contrato estabelecido pelo Ministério das Relações Exteriores do Brasil sendo que maior parte desses professores era requisitada da Universidade Brasil, depois UFRJ, e universidades de São Paulo e Paraná.

16 Alguns outros nomes e iniciativas devem ser ainda ressaltados, tais como o do historiador Guy de Hollanda, ${ }^{13}$ um dos primeiros professores universitários a compor um grupo de docentes e intelectuais a estabelecer-se em Assunção. Foi responsável, durante vários anos, pelas cátedras de História, Literatura e Português. Teve papel fundamental na fundação da Faculdade de Humanidades, no início da década de 40, que daria origem após alguns anos a Faculdade de Filosofia da Universidade Nacional de Assunção. Outros, como Paulo de Carvalho Neto, ${ }^{14}$ criador do primeiro curso de Antropologia, ligado à Faculdade de Filosofia . No final dos anos 50 funda com demais intelectuais do país, o Centro de Estudos Antropológicos, CEA, hoje um dos centros de pesquisas antropológicas mais ativos da America do Sul, o CEADUC, Centro de Estudos Antropológicos da Universidade Católica de Assunção. Escreveu inúmeros livros sobre arte popular latino americana (ver nota anterior). Outro nome a ser lembrado é o de Fernando Saturnino de Britto, arquiteto que manteve no Brasil proximidade com Lucio Costa, Afonso Reidy e Niemeyer. Saturnino instalou-se definitivamente naquele país nos anos 50 e acompanhou a execução do projeto de Reidy para a construção do Colégio Experimental Paraguai Brasil; Walter Wey, pesquisador da literatura latino-americana, autor de La poesía paraguaya, historia de una incógnita ${ }^{15}$; Lourenço Filho, educador, fundador e depois diretor do INEP (Instituto Nacional de Estudos Pedagógicos) de 1938 a 1946, autor de livros e projetos educacionais em todo o Brasil. Esteve no Paraguai em 
1944, envolvido com o projeto de construção da Escola Experimental Paraguai-Brasil, contribuindo especialmente para a elaboração do programa pedagógico ${ }^{16}$; Ary da Matta, professor e autor de livros de História do Brasil; Edson Motta, um dos maiores nomes no ensino de restauração do Brasil, mestre na Escola de Belas Artes do Rio de Janeiro. Empenhou-se ao lado de Livio Abramo para a criação do IPHAN; Álvaro Vieira Pinto, professor de Filosofia e um dos fundadores do ISEB - Instituto Superior de Estudos Brasileiros, um dos pilares das reformas de base defendidas no governo Jango Goulart. No Paraguai deu uma assistência pedagógica para o Colégio Experimental; Roquette Pinto, no Brasil médico, antropólogo e comunicador,e, no Paraguai, foi criador da cátedra de Fisiologia na Universidade do Paraguai, a musicista Esther Motta Coelho, aluna do maestro Villa Lobos, organizadora do primeiro ensino orfeônico em Assunção, entre outros.

17 A relação dos artistas locais com a Missão Cultural desde a sua implantação, ao que tudo indica, era de muita cordialidade. Tanto com os agrupamentos diretamente vinculados às iniciativas oficiais, quanto com os artistas que buscavam alternativas mais independentes, abrigando mostras de arte e manifestações culturais promovidas por centros estudantis. Em 1953, registra-se a primeira mostra fotográfica realizada pela Missão Cultural na sede do Instituto Cultural Paraguay-Brasil, ICPB, de um acervo pertencente à Divisão Cultural do Ministério das Relações Exteriores do Brasil de obras do escultor brasileiro Aleijadinho. Por tratar-se de um artista de grande significado para a cultura brasileira, a cobertura da imprensa e a presença do público em geral, especialmente, do setor educativo e das autoridades paraguaias, foi intensa. A exposição ocupou os dois salões do ICPB e compreendia 280 registros fotográficos das obras religiosas de Antonio Francisco Lisboa, particularmente de seus trabalhos realizados para as igrejas das cidades históricas mineiras.

Por certo não será exagero afirmar que o empenho dos intelectuais brasileiros no Paraguai e de dezenas de profissionais, brasileiros e paraguaios, vinculados direta ou indiretamente à Missão Cultural ou à Chancelaria Brasileira, a partir das primeiras experiências dos anos 40, tenha propiciado as condições internas necessárias para a realização do conjunto das ações culturais desenvolvidas por Lívio Abramo a partir dos anos 60 .

\section{Viver onde se produz}

19 "O lugar mais adequado para um artista é o lugar onde ele consegue produzir artisticamente. Seja aqui, na Europa ou no deserto do Saara". A frase proferida por Lívio Abramo, em 1990, para o jornal brasileiro Diário da Manhãa, ${ }^{17}$ na cidade de Assunção, responde a muitos questionamentos que ele recebia, por ter escolhido o Paraguai para viver. Ao mesmo tempo, nos levanta a possibilidade de refazer parte da trajetória do artista no Brasil e as razões que o levaram a fazer tal escolha.

No Brasil, Lívio Abramo nunca se dedicou, exclusivamente, ao seu próprio trabalho artístico, apesar de destacar-se como gravador já no final dos anos 40 . Suas atividades artísticas sempre foram entremeadas por compromissos da ordem da sobrevivência ou da militância política partidária ou sindical. A descontinuidade em seu ritmo de produção de gravura, em especial, chegando a intervalos de quatro ou cinco anos, o acompanha também no Paraguai. Mesmo depois de muito tempo, sem exercer a militância política ou o jornalismo e, de certa forma, estabilizado financeiramente, 
Lívio julgava-se um artista bissexto por reconhecer uma ausência de regularidade na produção de suas obras. Depois de muitos anos, acreditava ainda que a sua única profissão era o jornalismo, pois era daí que provinha o sustento regular de sua família e não da Arte. Certa vez, ao ser entrevistado pelo jornal paulista Última Hora sobre o reconhecimento da gravura brasileira no exterior, afirmou que o ritmo imposto aos artistas pelas seguidas bienais pressionavam-nos a produzir em ritmo acelerado. Reconhecia que, como outro profissional, o artista não poderia ignorar as oportunidades oferecidas pela sociedade, mas para ele, a produção artística deveria surgir de uma necessidade interior do artista e não por contingências exteriores.

21 As primeiras gravuras datam de 1926, embora já desenhasse, anteriormente, com certa frequência. Até os 31 anos, quando realizou a sua primeira coletiva ${ }^{18}$, Lívio colocou suas habilidades a serviço da política. Inicialmente, para o jornal do partido comunista, onde militou no início dos anos 30 e, em seguida, em 1933, para a construção do partido socialista. São dessa época ilustrações para panfletos políticos, muitos entregues em campanhas sindicais nas portas das fábricas paulistas. Antes dos anos 30, o artista fez ilustrações para diversos jornais italianos, como por exemplo os anarquistas Spagueto e L'Arrotino.

22 Aracy Amaral em seu Arte para quê ? escreve sobre o pioneirismo de Lívio Abramo ao estabelecer uma relação direta entre as suas criações plásticas, a militância e a preocupação social. Destaca, como exemplo, os desenhos e gravuras produzidas por Lívio sobre a Guerra Civil Espanhola na segunda metade da década de 30, o único artista brasileiro a fazê-lo. ${ }^{19} \mathrm{O}$ comprometimento político do artista, ressaltado por Amaral é compartilhado por vários críticos brasileiros como Geraldo Ferraz (1905-1979) e Mario Pedrosa(1900-1981), com os quais esteve ligado, em várias ocasiões. Para Pedrosa, Lívio era " o primeiro artista [...] a transpor para a xilo o tema da luta de classe: o operário na fábrica, o operário coletivamente em protesto, a velha fábrica de tecidos com o seu perfil recortado". ${ }^{20}$

Em 1931, iniciando no Diário da Noite, Lívio Abramo faz algumas ilustrações para o jornal, mas sua principal ocupação naquele periódico era como redator-titulador da correspondência nacional e internacional ${ }^{21}$. Essa função foi exercida durante 30 anos, só interrompendo quando mudou-se para o Paraguai.Com exceção dos dois anos em que viveu na Europa, como prêmio obtido no $54^{\circ}$ Salão Nacional de Belas Artes do Rio de Janeiro, em 1950, somente naquele país, segundo Regina Duarte ${ }^{22}$, o artista pôde viver dedicando-se, exclusivamente, à produção e ao ensino da arte.

Boa parte do tempo em que esteve no Diário da Noite, Lívio conviveu com o jornalista político e crítico de arte, Geraldo Ferraz, que em 1955, em uma publicação organizada pelo MAM de São Paulo, escreveu sobre a importância do trabalho naquele periódico para a formação gráfica de Lívio Abramo. Afirmou que o contato constante de Lívio com os acontecimentos políticos internacionais e a sua preocupação social o motivaram a expressá-los de uma maneira artística. ${ }^{23}$

Em seu livro autobiográfico denominado Depois de Tudo ${ }^{24}$, Ferraz fornece um quadro detalhado dos acontecimentos políticos e sociais dessa agitada São Paulo dos anos $30 \mathrm{e}$ 40, da qual Lívio foi testemunha. Época em que o cenário político de confronto entre paulistas e o governo Getúlio Vargas, que culminaria na frustrada Revolução de 32, provocava profundas repercussões nos principais jornais brasileiros. 0 crítico testemunhou em algumas ocasiões, momentos decisivos de Mario Pedrosa e Lívio Abramo. Um deles foi no periódico 0 Homem Livre. ${ }^{25}$ Mario Pedrosa assinava uma coluna de cinema com o pseudômino Alpheu Paraná e Lívio Abramo fazia as ilustrações do 
periódico que tinha como redator-chefe o próprio Ferraz. Foi nesse mesmo semanário que a palestra proferida por Mário Pedrosa sobre a mostra de gravuras da alemã Käthe Köllwitz, em 1933, foi publicada. Sob o título As tendências sociais da arte e Käthe Köllwitz, seu conteúdo sintetizou o pensamento da intelectualidade e de artistas simpáticos à temática social desenvolvida pela artista. ${ }^{26}$

A mostra da artista alemã é, sem dúvida, um referencial na trajetória do artista, pois o colocou em contato com uma obra que equilibrava o virtuosismo gráfico e a expressividade fortemente marcada pela problemática social, com a qual identificava sua própria produção na xilogravura.

Alguns anos antes de estabelecer-se no Paraguai, o gravador brasileiro Lívio Abramo iniciou seus primeiros contatos com os artistas e intelectuais daquele país e realizou, a partir dessa data, algumas atividades que marcariam a sua presença no meio artístico e que seriam fundamentais no processo de preparação para a sua ida definitiva para o Paraguai, ocorrida em outubro de 1962.

Em 1959, Abramo organizou uma grande exposição no Paraguai com as obras do acervo do Museu de Arte Moderna (MAM) de São Paulo e deu início à organização da segunda atividade expositiva importante, desta vez exibida no Brasil, que foi a mostra Arte Religiosa das Antigas Missões do Paraguay, para a VI Bienal de São Paulo, em 1961, como mencionado anteriormente.

No mesmo ano, Lívio Abramo envolveu-se na organização da mostra das rendas ñandutis para a V Bienal Internacional de São Paulo, visitando os povoados de Itauguá, Ypacaraí, Yaguarón, próximos a Assunção. 0 artista era diretor artístico do MAM na época em que o Museu de Arte Moderna era ainda a instituição responsável pela organização da bienal internacional. A correspondência entre o secretário geral da bienal, Arturo Profili e o Ministério de Educação e Cultura do Paraguai dão conta do envolvimento de Lívio Abramo e da Missão Cultural Brasileira nesse evento.

Nessa bienal, foi destinada uma sala especial denominada Ñanduti, e em outras salas foram exibidas obras de artistas paraguaios que também fizeram parte da delegação do país, como Maria Adela Solano Lopez, Olga Blinder e Lotte Schultz, as três artistas fundadoras do Taller de Grabado, além de Hermann Guggiari, Leonardos F. Torfs, Laura Moscarda e Carlos Colombino. Acompanharam a comitiva em São Paulo, os paraguaios Ramiro Domínguez e Juan Santiago Dávalos além do arquiteto brasileiro Saturnino de Britto. ${ }^{27}$

31 Todas essas realizações, organizadas por Lívio Abramo antes mesmo de transferir-se para o Paraguai, revelam um propósito do artista de participar de um circuito cultural proporcionado pela sua posição privilegiada não só como um dos mais importantes gravadores da época, mas como membro do Conselho Artístico do Museu de Arte Moderna, de São Paulo, ligado à organização das bienais, desde as primeiras edições.Pode-se dizer que de 1956 a 1962, houve uma espécie de sondagem de possibilidades artísticas e, com certeza, de avaliações de interesses concretos de ambos os lados, que resultaram em uma articulação diplomática vitoriosa com a nomeação de Abramo para a coordenação do setor de artes visuais.

Nessa seção procuraremos abordar quais teriam sido esses interesses que culminaram na formação de um sólido programa artístico-cultural no Paraguai, coordenado por Lívio Abramo. Programa esse, que possibilitou a criação um terreno cultural 
compartilhado pelos dois países por mais de 30 anos, com poucos precedentes na história das relações culturais entre os povos da America Latina.

Antes da crise política instalada no Brasil em 1961, resultado da renúncia de Jânio Quadros, e que desembocaria após três anos na implantação do regime militar, as conversações para a ida de Lívio Abramo ao Paraguai haviam se iniciado entre membros do governo brasileiro e alguns intelectuais daquele país. Convidado a ir a Brasília, pelo antropólogo Darcy Ribeiro, um dos ministros de Jango Goulart (1961-1964), Ramiro Dominguez, um dos principais articuladores da ida de Livio ao Paraguai, bem como o arquiteto brasileiro Saturnino de Britto foram os porta-vozes da proposta de se criar um setor de artes plásticas naquele país, através da Embaixada Brasileira bem como da indicação do nome de Lívio Abramo.

Para o Brasil, especialmente para o Itamaraty, a permanência de Lívio Abramo naquele país, inicialmente prevista para dois anos, representava uma ampliação das ações do Departamento Cultural do Ministério das Relações Exteriores (MRE), intensificadas na gestão de Mario Dias Costa e Lauro Escorel de Moraes, dois dos nomes mais destacados da história da Diplomacia Cultural do Brasil. A antiga militância política e sindical do artista, em agrupamentos da esquerda paulista dos anos 30, parece não ter constituído empecilho para sua nomeação, diante do estatuto de artista já consagrado por prêmios, por participações nas bienais, pelas articulações com o meio artístico e, por certo, pelas afinidades políticas encontradas entre os dirigentes do departamento cultural, no Itamaraty.

Para o embaixador Rubens Ricupero, ex-integrante do Departamento de Cultura do Itamaraty nos anos 70 , chefe da Divisão Cultural no período Médice ${ }^{28}$, houve pouca interferência do governo militar na política cultural do Itamaraty. Ricupero visitou pessoalmente Lívio em Assunção, no início dos anos 80, e pôde comprovar a dimensão do trabalho do artista no meio da sociedade paraguaia. 0 embaixador assegurou que mesmo com a vigência dos atos de exceção, durante o período militar no Brasil, a política cultural em relação ao Paraguai não sofreu nenhuma interrupção uma vez que sua implantação era anterior ao golpe, desde Vargas. Adverte, entretanto, que " houve sim interferência dos órgãos de segurança no sentido de não se promover artistas que de alguma forma estivessem vinculados a algum movimento de esquerda". ${ }^{29}$

36 A experiência individual de Lívio Abramo em circulação no meio artístico e intelectual de São Paulo, especialmente nos anos 50, quando ocupou seguidas vezes o cargo de diretor do Museu de Arte Moderna e, por extensão da Bienal de São Paulo ${ }^{30}$, abre a possibilidade de estabelecer junto àquela comunidade artística um programa de ações culturais, elaborado gradualmente, uma vez que a sua condição de funcionário "temporário" não lhe permitia fazer projetos duradouros.

Precisar as reais intenções que impulsionaram a ida de Lívio Abramo ao Paraguai, bem como a sua permanência naquele país por longos anos, é um exercício reflexivo que leva a inúmeras possibilidades. Há vários depoimentos do artista reconstituindo a passagem de sua trajetória e como também há muitas interpretações no meio dos artistas e intelectuais, contemporâneos de Lívio. Ao ser entrevistado ou ao proferir palestras, Lívio citava repetidas vezes algumas passagens de sua vida. Uma espécie de memória-hábito, como definiria Henri Bergson, cuja repetição não era um simples ato mecânico, mas a afirmação de uma história de vida que o fazia sentir orgulho e desejar ser reconhecido dentro de um determinado padrão de valores éticos. 


\section{Modernidade artística} paralelamente aos mandos e desmandos da ditadura, um caminho alternativo ideologicamente reverso à situação recém estabelecida, que acomodou muitos artistas e intelectuais. No livro biográfico de Olga Blinder, a autora menciona a definição das duas alternativas que se colocavam para a sociedade paraguaia naquele momento: a primeira, baseava-se na liberdade, no crescimento, na denúncia, na solidariedade e democracia, em contraposição ao caminho da opressão, violação dos direitos humanos, submissão e autoritarismo ${ }^{33}$.

Para compreender a receptividade da comunidade artística do Paraguai em relação às iniciativas de Lívio Abramo, faz-se necessário analisar as aspirações dos artistas ligados ao Grupo Arte Nuevo bem como a postura dos intelectuais, dispostos naquele momento a apoiar propostas que ajudassem a impulsionar o meio cultural e a apoiar novas experimentações artísticas.

Mônaco e Laterza Parodi, o Grupo Arte Nuevo representava a vanguarda no campo da arte. Esse mesmo grupo, acrescido posteriormente por outros artistas, foi o responsável pela realização da Semana de Arte Moderna no Paraguai, em 1954, a partir da qual os artistas, formados em sua maioria no próprio país, desencadeiam um processo de modernização na arte. A preocupação desses artistas estava centrada em acompanhar as inovações que circulavam no cenário artístico internacional, como já foi mencionado, e, ao mesmo tempo, em resolver questões concretas da relação da arte com a necessidade do próprio meio.

ansição ocorrido em momentos anteriores - início dos anos 50 - no qual artistas como Jaime Bestard, Ofélia Echagüe Vera, Bandurek Wolf, Holden Jara e outros, começam a acercar-se das novas contribuições das vanguardas internacionais, sem romper, contudo, com alguns parâmetros presentes na tradição artística. Afirma que "[...] aún aislados entre si $y$ desfasados con respecto a su tiempo, los artistas comienzan a incorporar nuevos elementos y planteamientos que no implican, todavía, una ruptura con la visión tradicional, pero constituyen la base sobre la que se apoyarán y crecerán las nuevas formas". ${ }^{31}$

Alfredo Stroessner chega ao poder e implanta uma das mais longas e viol ditaduras registrada na América Latina (1954-1989). Desse período surge a expressão cunhada por Escobar de modernidad quebrantada, para explicar um difícil processo de modernização diante de uma conjuntura política extremamente desfavorável. Por um lado, esse processo foi "espremido" pelo ideário do regime militar e, por outro, por mediações estrangeiras, que ele denominou de hegemônicas oriundas, principalmente, das submetrópoles, como São Paulo e Buenos Aires. ${ }^{32}$

O processo de renovação na arte, impulsionado pelo Grupo Arte Nuevo, construiu Quando Lívio Abramo chega ao Paraguai a agenda da modernidade já havia sido incorporada às aspirações do meio cultural, o que não significava, entretanto, segundo Escobar, que seus principais postulados estivessem resolvidos pela prática artística vigente. Como solucionar os conflitos, colocados pela arte moderna, entre a autonomia da forma e a necessidade de referir-se a uma história concreta, ao meio circundante. Para Escobar, a figura de Lívio e o seu próprio trabalho como artista são fundamentais 
para consolidar esse momento. "Lívio consegue com a sua própria obra, especialmente com a série Paraguay, produzir uma síntese dessas questões. Trabalha com uma geometrização muito depurada referindo-se, entretanto, a uma história local, com igual força. Aqui no Paraguai ele consegue unir esses dois polos, que no Brasil, vemos em momentos separados", ${ }^{34}$ afirma.

Por meio da coordenação e docência nas oficinas de arte, Lívio Abramo interferiu ativamente nesse processo de mudança das artes do Paraguai, colaborando para romper as fronteiras que isolavam o meio artístico local das experiências internacionais.

Aulas de História da Arte durante uma exposição em Assunção.Acervo particular

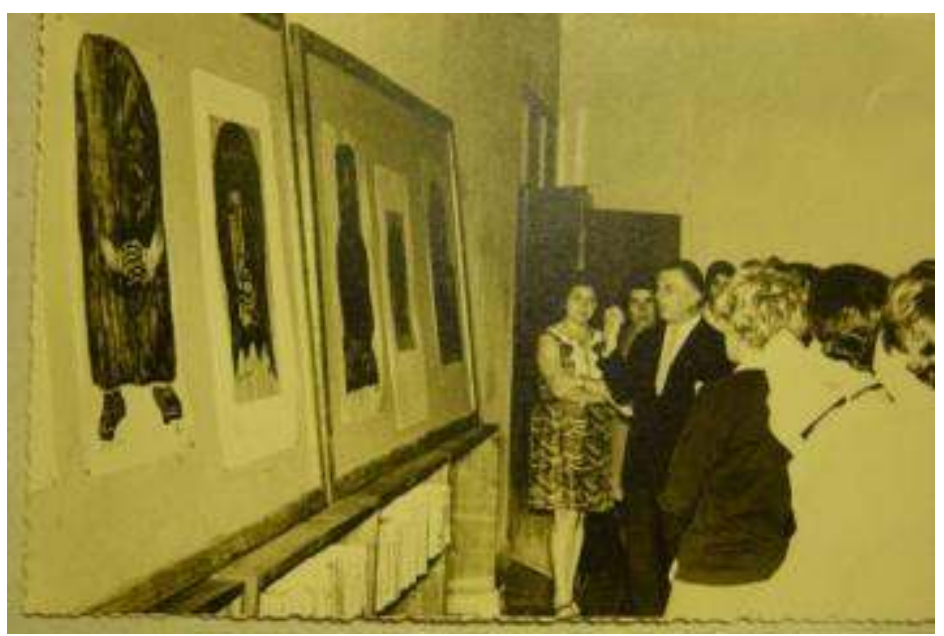

Cerca de 200 exposições de arte, contabilizadas pelo próprio Lívio Abramo, número confirmado nos depoimentos de artistas e críticos paraguaios, construíram um território comum de aprendizado e experimentação artística, pois muitos artistas que faziam exposições no Paraguai também realizavam oficinas ou palestras com os artistas locais, como foi o caso de Maria Bonomi ou da argentina, radicada no Brasil, Maria del Carmen Perez Sola. Em 1989, em um dos relatórios enviados ao Brasil para a Divisão Cultural do Itamaraty, Lívio escreve: "Nestes 27 anos de trabalho realizamos mais de 200 exposições que incluíram os melhores artistas brasileiros e paraguaios, o todo selecionado dentro de uma severa escala de valores que tornaram o Centro de Estudos Brasileiros uma das mais acreditadas instituições culturais existentes no Paraguai". ${ }^{35}$

Em muitas de suas entrevistas, Lívio Abramo dizia que já havia acompanhado muitas transformações no mundo, pelo fato de ter nascido no início do século XX. Seu tempo de vida o colocaria, no mínimo, na condição de "observador participante" de grandes acontecimentos, para usar a expressão cunhada pelo historiador Eric Hobsbawm..$^{36} \mathrm{O}$ breve Século XX é definido pelo historiador como a era das grandes esperanças e grandes tragédias, construída em torno das guerras, das revoluções socialistas, das crises econômicas, do desmoronamento dos antigos impérios, do início e fim da Guerra Fria, e de tantos outros acontecimentos, que no Brasil, tiveram profundas repercussões.

São Paulo, nessa primeira metade do século, também foi palco de agitados acontecimentos políticos, tais como os movimentos de resistência contra a ditadura Vargas, de 1930 a 1945, e o surgimento da frente anti-integralista; a Revolução Constitucionalista de 32, e demais fatos, como a Intentona Comunista, em 1935, e a instalação do Estado Novo, em 1937, com repercussões diretas em São Paulo. 
Como já foi mencionado, Lívio Abramo não só acompanhou, como também, em alguns momentos, participou ativamente em várias frentes de organização das esquerdas, tais como a criação de sindicatos de trabalhadores em São Paulo, das ações do Partido Comunista e depois do Partido Socialista, e, como ilustrador dos veículos de comunicação desses organismos ${ }^{37}$.

9 No campo artístico, a mesma longevidade reivindicada pelo artista para explicar seu lugar como testemunha de grandes acontecimentos, colocou-o próximo a momentos significativos da história da arte brasileira, particularmente em São Paulo, onde paralelo à movimentação política, tiveram lugar nessa mesma época, importantes realizações culturais, pós Semana de 22. São dessa época as iniciativas de fundação de associações e clubes de artistas, tais como a Sociedade Pró-arte Moderna (SPAM), em 1932, que reunia os artistas modernos da primeira geração e, no mesmo ano, o Clube dos Artistas Modernos (CAM), com Flávio de Carvalho à frente; o Grupo Santa Helena, formado por artistas imigrantes ou descendentes ${ }^{38}$; a Oficina de Arte ODA ${ }^{39}$, entidade criada a partir da associação de demais entidades artísticas; o Sindicato dos Artistas Plásticos, em 1937, desdobramento da Sociedade Paulista de Belas Artes, de 1921, e a criação dos salões anuais - o Salão de Outono, em 1930, o Salão de Maio, em 1937, e o Salão da Família Artística Paulista (FAP).

No final dos anos 40, São Paulo vê surgir os primeiros museus filiados às concepções modernistas de museu vivo, com programas e espaços educativos definidos, tais como o Museu de Arte de São Paulo (MASP), em 1947, e o Museu de Arte Moderna (MAM), em 1948, instituição responsável pela realização das primeiras bienais internacionais de arte.

51 São dessa época, os registros das primeiras iniciativas voltadas para a arte educação em museus, estimuladas pelos propósitos da modernidade paulista de formar uma nova mentalidade cultural. A criação do Clube Infantil de Arte do MASP, coordenado por Suzana Rodrigues, representa, conforme sugere a pesquisadora Rita Bredariolli ${ }^{40}$, a primeira iniciativa, em museus, a desenvolver um programa de arte educação para um público infantil fixado entre 5 a 12 anos.

52 O meio cultural presencia o surgimento nessas décadas, de publicações periódicas voltadas para a arte e cultura ${ }^{41}$, e nos jornais, os críticos passam a ter presença assídua nas colunas de artes plásticas e de literatura, tais como: Geraldo Ferraz, Luis Martins, Mario Pedrosa, Sergio Milliet, Lourival Gomes Machado, Osório César, José Geraldo Vieira, Roger Bastide, Maria Eugênia Franco, Ciro Mendes, Ibiapaba Martins, e dos anos 20 aos 40, a significativa contribuição de Mario de Andrade para a crítica de arte e literatura brasileiras, presença constante nos jornais de São Paulo.

Os salóes de arte e os clubes de artistas não eram somente meros espaços expositivos para a apresentação dos artistas brasileiros. Esses salões tiveram o mérito de apresentar as primeiras mostras do modernismo internacional e de exercer um papel de fomentadores das discussões entre grupos de artistas e críticos, dos temas mais candentes do processo de modernidade nas artes, impulsionado no Brasil desde a Semana de 22. Portanto, constituíram-se em espaços de reafirmação desses propósitos. Lívio Abramo participou do último Salão de Maio, em 1939, dirigido pelo arquiteto Flávio de Carvalho, ao lado dos artistas da primeira geração modernista, como Tarsila do Amaral, Anita Malfatti, Di Cavalcanti, Lasar Segall. Mesma oportunidade em eu se apresentaram também os artistas ligados ao Grupo Santa Helena. 


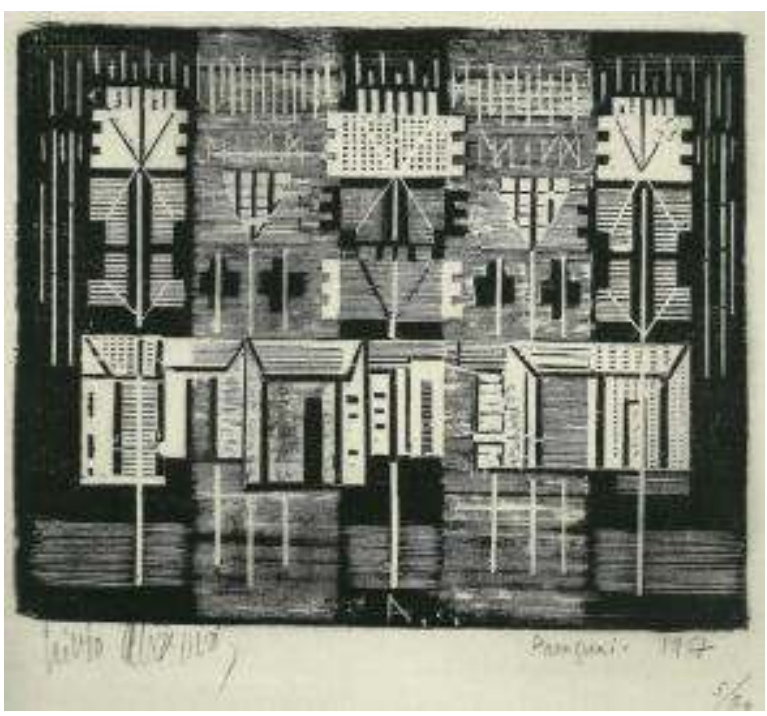

Fonte: Araújo, Lívio Abramo,2006 arte de São Paulo, consolidou-se a tendência à internacionalização das exposições de arte no Brasil, e novas questões mobilizavam a crítica de arte e os artistas. Se a mostra de Käthe Kollwitz, em 1933, e, o discurso de Mario Pedrosa publicado no O Homem Livre, foram marcos propulsores para as discussões sobre a função social da arte nos anos 30, a inauguração do MAM de São Paulo, em 1949, com a mostra Do Figurativismo ao Abstracionismo ${ }^{42}$, e no ano anterior, o discurso de Di Cavalcanti em defesa dos pressupostos do modernismo brasileiro, exerceram semelhante importância para estimular a atualização das discussões no meio artístico. Indagações tais como "para onde vai a arte ?" com acaloradas discussões sobre o Figurativismo e o Abstracionismo, marcam o debate da década, segundo a historiadora e crítica de arte Lisbeth Rebollo. ${ }^{43}$

No campo da política cultural, o pensamento da elite paulista, após a fracassada Revolução de 1932, voltou-se para a defesa de investimentos nas áreas de educação e cultura. Como bem ressaltou Rita Bredariolli ${ }^{44}$, políticos liberais e intelectuais modernistas, movidos por interesses "parcialmente comuns" articulam-se entorno da criação da Escola Livre de Sociologia e Política de São Paulo (ELSP), em 1933, e, um ano mais tarde, para a fundação da Universidade de São Paulo.

o projeto ideológico que estava na base dessas iniciativas era a formação de uma elite dirigente capacitada para exercer com competência e conhecimento da realidade social, cargos administrativos ou técnicos e também, para exercer as funções de educadores na sociedade paulista. Alguns nomes como Julio de Mesquita Filho, Rubem Borba de Moraes, Paulo Duarte, Armando Sales de Oliveira e Sergio Milliet estiveram presentes, desde o início, à frente dessas instituições. Este último, além de ter sido um dos fundadores da ELSP, exerceu os cargos de diretor, docente e tesoureiro naquela instituição, e teve papel de destaque para a consolidação de uma política cultural em São Paulo. Sergio Milliet foi diretor de uma das divisões do Departamento de Cultura do Município de São Paulo, dirigido por Mario de Andrade, e, em 1945, foi responsável pela criação da Seção de Arte da Biblioteca Municipal, espaço destinado às mostras de arte e a realização de debates ou encontros entre os artistas. ${ }^{45}$ 
Muitas dessas passagens nas quais o artista esteve presente, foram mencionadas nesse trabalho, restando, entretanto, muito ainda a ser investigado como, por exemplo, a sua convivência com os artistas do Rio de Janeiro, de 1948 a 1950, enquanto lá viveu, e que teria inspirado a produção de algumas de suas principais séries de gravuras, tais como Rio e Festa, ou ainda, a sua permanência de dois anos na Europa, de 1951 a 1953. Como esclarecemos, restringimo-nos aos principais acontecimentos que podem contribuir para o entendimento do cenário, dentro do qual foi tecida a trajetória do artista Lívio Abramo.

58 Quando a artista paraguaia, Fabíola Adam afirma que Lívio chegou ao Paraguai um homem completo, um artista consagrado ${ }^{46}$, ela não está fazendo uso de nenhuma concepção determinista em relação às novas possibilidades de aprendizado do artista. Está se referindo, muito provavelmente, a essa herança cultural e artística forjada na experiência do artista, a partir desse campo cultural específico, esse espaço de interação entre intelectuais, artistas e forças políticas da São Paulo dos anos 30 até final dos 50, período de reafirmação do modernismo nas artes.

\section{Cultura e poder}

Embora considere relevante o estudo da historiadora Ceres Moraes para a compreensão das relações entre Brasil e Paraguai, dos anos 50 aos 70, suas conclusões sobre o papel da Missão Cultural Brasileira, para o estreitamento entre as ditaduras militares dos dois países, esbarram nas ferramentas oferecidas pelos estudos específicos da geopolítica, campo que oferece, aliás, outras possibilidades de reflexão.

As ditaduras da America Latina se apoiaram, não resta dúvidas, o que não implica dizer que todos os atos do governo brasileiro, tenham sido pensados para apoiar o governo de Stroessner,e, que a Missão Cultural Brasileira, gestada ainda no governo Getúlio Vargas e implantada ao longo da década de 40 e 50, tenha sido pensada para esse fim.Em 1987, a pesquisadora Mônica Hertz, do Instituto de Relações Internacionais, o IRI, da Puc do Rio de Janeiro, ${ }^{47}$ reconhece a legitimidade do uso da interdisciplinaridade para os estudos da cultura no âmbito das políticas internacionais. Hertz admite como fundamental para a análise dessa questão, a aproximação dessa área de conhecimento, ou seja, das Relações Internacionais, a outras áreas, cujas teorias "buscam superar os limites dos estudos clássicos incorporando as intervenções não estatais, e considerando as aproximações e interelações entre o sistema internacional e os contextos nacionais".Para o pesquisador francês Alain Rouquié, ${ }^{48}$ estudioso das questões político-militares na America Latina, a consolidação do poder de Stroessner nesse período está relacionada diretamente ao jogo de forças internas de poder desencadeado pessoalmente pelo general contra, inclusive, os próprios militares não alinhados de seu partido, e, contra os seus opositores frontais, explícitos. No plano internacional ele se fortalece devido ao seu alinhamento com Washington na luta contra o comunismo, "onde ele não teve rival". ${ }^{49}$ Pelas características analisadas do governo Stroessner, Rouquié afirma que a ditadura instalada no Paraguai foi uma ditadura pessoal e que mesmo considerando o Exército próximo do poder, não é ele quem governa, e "Stroessner não é absolutamente o seu portavoz". ${ }^{50}$ Afirma o historiador que o general conseguiu "antes de tudo, neutralizar a organização ( militar) através de meios diversos, dentre os quais a corrupção, que são legitimados e sustentados pela lógica partidária" ${ }^{51}$ 
61 Nesses anos de pesquisa, conversando com seus contemporâneos, pude constatar o reconhecimento do seu trabalho para a cultura paraguaia. Lívio Abramo colaborou para o fortalecimento de instituições que promovessem o acesso democrático de parcelas da população. No ensino da arte, priorizou a formação de um campo social da arte. Revalorizou culturas esquecidas e desprezadas das antigas missões conferindo-lhes estatuto de patrimônio cultural e trouxe o artesão, portador da tradição indígena para dentro da esfera da arte. Criou um território cultural comum entre Brasil e Paraguai, sedimentado na arte, na valorização das tradições locais e nas delicadas relações diplomáticas, com relativa independência. A obra cultural do artista no Paraguai foi resultado de uma conjunção de fatores: das condições oferecidas pela diplomacia brasileira; dos programas culturais, inicialmente desenvolvidos nas áreas da educação pelos primeiros professores da Missão Cultural; da receptividade da comunidade intelectual e artística do Paraguai, que acolheu as propostas levadas por Lívio,mas, sobretudo, foi resultado do compromisso social, das habilidades e vivências de Lívio Abramo no campo artístico e cultural, compartilhadas com a comunidade com a qual conviveu até seu falecimento.

\section{BIBLIOGRAFIA}

ALCALÁ, Javier Rodriguez. Reidy em Cachinga: da política do café com leite para a geopolítica do concreto armado. Revista de arquitetura Vitruvius, 2008.Disponível em https:// www.vitruvius.com.br/jornal. Acesso: jul,2008.

AMARAL, Aracy A. Arte para quê ? A preocupação social na arte brasileira 1930-1970. Estudio Novel/ Itaú Cultural, São Paulo, 2003.

AMARAL, Aracy A. (org.) Mundo, homem, arte em crise. Ed. Perspectiva, São Paulo, 1975.

AMARANTE, Leonor. As Bienais de São Paulo de 1951 a 1989. Projeto Editorial, São Paulo, 1989.ARAÚJO, Olívio Tavares de. A gravura de Lívio Abramo. Projeto Ateliê de Gravura/ Instituto Tomie Ohtake, São Paulo, 2006.BRASIL/ PARAGUAI. Lívio Abramo: 133 obras restauradas. Embaixada do Brasil no Paraguai/ Centro de Artes Visuais/ Museo do Barro, Assunção, 2001.

BREDARIOLLI, Rita. Das lembranças de Suzana Rodrigues. EDUFES, Vitória, 2007.

CARDOZO, Efraím. Apuntes de Historia Cultural del Paraguay, 2007. In: NETO, Paulo de Carvalho. Folklore del Paraguay: las culturas folklóricas, populares y mitológicas del Paraguay. El Lector, Assunção, 1997.

ESCOBAR, Ticio. El arte Fuera de Sí. Fondec/CAV-PY, Assunção, 2004.

ESCOBAR, Ticio. Una interpretación de las artes visuales en El Paraguay. Servi Libro, Assunção, 2007.

FERNÁNDEZ, Miguel Ángel (org.) Arte y Artistas de Brasil y Paraguay. El Lector/Ministério da Cultura do Brasil e Embaixada do Brasil no Paraguai, Assunção, 1999.

FERRAZ, Geraldo. Depois de Tudo. Ed. Paz e Terra. Secretaria Municipal de Cultura de SP. Coleção Depoimento, Rio de Janeiro/São Paulo, 1983. 
FERRAZ, Geraldo. Lívio Abramo. Col. A. B. C. Artistas Brasileiros Contemporâneos, n.5. Ed. Museu de Arte Moderna de São Paulo, São Paulo, 1955.

FERREIRA, Gullar. Debate sobre a Gravura Brasileira. Jornal do Brasil: Suplemento Dominical. Rio de Janeiro, 1957/1958.

GONÇALVES, Lisbeth Rebollo (org.). Sergio Milliet 100 anos, Trajetória, Crítica de Arte e Ação Cultural. ABCA, São Paulo, 2005.

GONÇALVES, Lisbeth Rebollo (org.). Sergio Milliet, Crítico de Arte. São Paulo: Ed. Perspectiva/Edusp, 1992.

GOOSSEN, Teresa. Olga Blinder, una biografia. Goosen Libros, Assunção, 2004.

HERTZ, Mônica. A dimensão cultural nas relações internacionais: proposta teórico-metodológica. In Contexto Internacional no.6. Rio de Janeiro, junho/dezembro de 1987.

HYDER, S.W. About Prints. Gravura Macumba (1957), Livio Abramo, pg.10. Oxford University Press, Londres, 1962.

HOBSBAWM, Eric.Era dos Extremos, o breve século XX. 1914-1991. Cia das Letras, São Paulo, 1999. HOFFMANN, Ana Maria Pimenta. Crítica de Arte e Bienais: as contribuições de Geraldo Ferraz. Tese/ ECA - Escola de Comunicações e Artes da Universidade de São Paulo, 2007.

LAUDANNA, Mayra. Maria Bonomi: da gravura à arte pública. EDUSP, São Paulo, 2007.

MORAES, Ceres. A consolidação da ditadura Stroessner, 1954-1963. EDPUCRS, Porto Alegre, 2000

MOTA, Carlos Guilherme. Brasil em Perspectiva. Bertrand Brasil, Rio de janeiro, 1988.

NEPOMUCENO, M.M.C. Livio Abramo no Paraguai: entretecendo culturas. Dissertação de mestrado. Prolam/Universidade de São Paulo, 2010.

ODÁLIA, Nilo. O Brasil nas Relações Internacionais: 1945-1964. In: MOTA, Carlos Guilherme (org). Brasil em Perspectiva. Coleção Corpo e Alma do Brasil. Fernando Henrique Cardoso e Boris Fausto. Rio de Janeiro: Ed. Bertrand Brasil, Rio de Janeiro, 1988.

PAZ, Alfredo Boccia; GONZÁLEZ, Myrian, e PALAU, Rosa. Es mi informe: los archivos secretos de la política de Stroessner. Servi Libro, Assunção, 1996.

PEDROSA, Mario. Política das Artes . ARANTES, Otília (org). EDUSP, São Paulo,1995.

PEDROSA, Mario. Despedida de Lívio Abramo. (Rio de Janeiro, 12 ago 1951). In: ARANTES, Otília (org). Acadêmicos e Modernos. Vol.3. EDUSP, São Paulo, 2004, pg.225-226.

PEDROSA, Mario. Entre a Semana e as Bienais. In: AMARAL, Aracy A. (org). Mundo, Homem, Arte em Crise. São Paulo: Ed Perspectiva, 1975. pg 269.

PINSKY, Jaime. O Brasil nas Relações Internacionais: 1930-1945. In MOTA, Carlos Guilherme (org). Brasil em Perspectiva. Coleção Corpo e Alma do Brasil. Fernando Henrique Cardoso e Boris Fausto.Ed. Bertrand Brasil, Rio de Janeiro, 1988.

RIBEIRO, Edgard Telles Ribeiro. Diplomacia Cultural: seu papel na Política Externa Brasileira. Brasília: Fundação Alexandre de Gusmão e IBRI- Instituto Brasileiro de Relações Internacionais/UNB, 1989.

RODRIGUES, Marly. Imagens do Passado: a instituição do Patrimônio em São Paulo, 1969-1987. UNESP/ CONDEPHAT, São Paulo, 2000.

RUFINONI, Priscila Rossinetti. No lusco-fusco da modernidade: Osvaldo Goeldi e a crítica. Crítica e Modernidade. Annatereza Fabris(Org.). ABCA, São Paulo, 2006. 
ROUQUIÉ, Alain. O Estado militar na América Latina. Trad.Leda Rita Cintra Ferraz. Ed. Alfa-Omega, Coleção Esta América, v.16, São Paulo, 1984.

SALUM-FLEXA, Antonio. Historia da Diplomacia del Paraguay: de 1869-1990. Edicão Comuneros, Assunção, 1990.

SILVA, Ronaldo Alexandre do Amaral e. Brasil-Paraguai: marcos da política de reaproximação bilateral, 1954-1973. Dissertação de Mestrado para o Instituto de Relações Internacionais (IREL) da Universidade de Brasília, 2006.

SILVA, Fátima. Livio Abramo: porque troquei o Brasil pelo Paraguai. Diário de Manhã, de Goiás. Entrevista concedida em Assunção, 3 de out. de 1990.

SIMONE, Eliana de Sá Porto de. Käthe Kollwitz. EDUSP, São Paulo, 2004.

VELASQUÉZ, Rafael Eladio. Breve História de La Cultura en el Paraguay. Editora da Universidade Católica Nossa Senhora de Assunção, Assunção,1999.

\section{Arquivos pesquisadosbrasil}

Itamaraty/Brasília. Centro de Documentação Histórica.(anos 30-60)BRASIL.

Itamaraty/Rio de Janeiro. Centro de Documentação Histórica.(anos30-60)BRASIL.

Embaixada do Brasil no Paraguai. Centro de Documentação Histórica.(50-90)BRASIL.

Departamento Cultural do MRE/Brasilia. Informativo sobre os Centros de Estudos Brasileiros ( antigas Missões Culturais Brasileiras), 2010.

SÃO PAULO- Arquivo do Estado de São Paulo.(anos 30-50)

SÃO PAULO- Museu de Arte Moderna (MAM). (anos30-50)

\section{Entrevistas à pesquisadora: Aquino}

Ricardo Caballero. Cônsul Geral do Paraguai no Rio de Janeiro. maio, 2010

ADAM, Fabíola. Artista plástica, professora universitária, ex-aluna de Livio Abramo. Assunção, jul 2007.

CUBERO, Estela Rodriguez. Restauradora, primeira presidente do IPHAN Paraguai. Assunção, set., 2008.

DUARTE, Regina. Assistente de museus de arte. Assunção, jul., 2007.

ESCOBAR, Ticio. Crítico de arte, ex-aluno de Livio Abramo e atual Ministro da Cultura do Paraguai.Assunção, jul, 2007.

FERNÁNDEZ, Miguel Ángel. Funcionário da Embaixada brasileira, professor universitário. Assunção, jul.,2008.

RICUPERO, Rubens. Ex-embaixador, professor universitário. São Paulo, ag. 2009. 


\section{NOTAS}

1. Convênio de Intercâmbio Cultural entre Brasil e Paraguai, assinado por Getúlio Vargas, em 1941. In. Atos Internacionais Concluídos entre Brasil e o Paraguai. Arquivo Histórico do Itamaraty-Brasília. Doc 910.31 (42) (43). Pasta 81.826; Imprensa Nacional. Rio de Janeiro, p. 7.

2. ABRAMO, Livio. Mostra de gravuras e artesania popular do Nordeste em Assunção. set. 1966. In. FERNÁNDEZ, Miguel Ángel (org.) Arte y artistas de Brasil y Paraguay, p. 30.

3. SILVA. Alberto Costa e. (org). O Itamaraty na Cultura Brasileira. Inst. Rio Branco e FUNAG. 2002; RIBEIRO, Edgard Telles. Diplomacia Cultural: seu papel na Política Externa Brasileira. PRI.1989.

4. A atual denominação da Missão Cultural Brasileira é Centro de Estudos Brasileiros. Esse programa vigora até hoje, com algumas modificações, em vinte e um países.

5. Foram criados talleres ou oficinas de gravura, desenho, pintura e cerâmica, além de um curso permanente de História da Arte.

6. O programa educativo das escolinhas de arte tinha como finalidade valorizar a expressividade da criança e a sua capacidade criativa em substituição aos velhos modelos pedagógicos. Seus preceitos fundamentais foram inspirados nas reflexões do crítico de arte inglês Herbert Read, para quem a “ expressão pela arte”, exercida com liberdade, porém, com orientação, teria como objetivo final o desenvolvimento integral das crianças, e não necessariamente a sua formação artística. NEPOMUCENO, Margarida. Livio Abramo no Paraguai: entretecendo culturas. p. 196.

7. CF. MORAES, Ceres. A consolidação da ditadura Stroessner, 1954-1963.p.100.

8. Idem, pg 102.

9. CF. PAZ, Alfredo Boccia; GONZÁLEZ, Myrian, PALAU, Rosa. Es mi informe: los archivos secretos de la política de Stroessner. p. 5-21.

10. CUBERO, Estela Rodriguez. Entrevista concedida à pesquisadora.

11. SILVA, Ronaldo Alexandre do Amaral e. Brasil-Paraguai: marcos da política de reaproximação bilateral, 1954-1973.p. 56.

12. Até o final da primeira metade do século $X X$, a MCB já estava operando em quatro países da América Latina. Depois de Montevidéu, em 1940, e Paraguai, foram criadas novas "missões".

13. Professor da Faculdade Nacional de Filosofia no Brasil e também no Paraguai, autor do primeiro levantamento sobre os museus existentes no Brasil do século XIX até os anos 50 (Recursos Educativos dos Museus Brasileiros, 1958), e de projetos educativos que serviram de base para a Reforma Capanema, de 1942, no âmbito da instituição definitiva da cadeira de História do Brasil. É autor de Um quarto de século de programas e compêndios de História para o ensino secundário brasileiro (1931-1956) e demais publicações.

14. Cientista social e escritor brasileiro, serviu a Missão Cultural Brasileira no Paraguai de 1950 a 1951. Autor de Folklore Del Paraguay (1960), Acentos Folkloricos del Ecuador (1976), El folklore de las luchas sociales (1973), Estudios de folklore (1973), Arte Popular del Ecuador (1970), Folclore Sergipano (1970), Antología del folklore ecuatoriano (1970), Historia del Folklore iberoamericano (1969), Estudios de Folklore I e II (1969), El carnaval de Montevideo (1967), Geografía del Folklore ecuatoriano (1964), Folklore y Educación (1961), Folklore y Psicoanálisis (1956), Concierto de Folklore (1956), e outros, alguns dos quais traduzidos para o inglês. Dicionário dos Folcloristas Brasileiros.

15. Para o crítico paraguaio Miguel Ángel Fernandez, Walter Wey já estava no Paraguai em torno de 1945-1946. "se vinculó a los más destacados intelectuais paraguayos de la época e investigo sobre nuestra poesia. No sé exactamente cuando dejó Paraguay, pero es probable que haya sido em 1946-1947. Después fue director del centro de Estudios Brasileños (na época Missão Cultural) de Montevideo, donde publicó su excelente libro sobre la poesia del Paraguay". Entrevista concedida à pesquisadora. 2008.

16. ALCALÁ, Javier Rodriguez. Reidy em Cachinga: da política do café com leite para a geopolítica do concreto armado. 2008.

17. Livio Abramo: porque troquei o Brasil pelo Paraguai. Diário de Manhã. 3 de out.de1990,p.[3]. 
18. No $2^{\circ}$ Salão Paulista de Belas Artes, em 1935, com a série Operários. In. ARAÚJO, Olívio Tavares de. Lívio Abramo, p. 172

19. AMARAL, Aracy. Arte para quê ? p. 36 .

20. PEDROSA, Mario. Entre a Semana e as Bienais. In. Mario Pedrosa. Mundo, homem, arte em crise. AMARAL, Aracy (org.), p. 278.

21. "Lívio começou naquele distante ano de 1931[...], onde se iniciou fazendo títulos de telegramas, nacionais e estrangeiros. Foi essa a sua participação jornalística mais constante, a atividade paralela que lhe permitia a subsistência, deixando-lhe sobras de dia e noite para fazer o que lhe agradava, desenhos e projetar gravuras". FERRAZ, Ferraz. Depois de Tudo, p. 95.

22. Regina Duarte é filha de Dora Guimarães Duarte - segunda esposa de Lívio, já falecida-. Depoimento a pesq., jul de 2007.

23. "Foi nesse esforço para domar a realidade e transfigurá-la, na conduta de sua vida de participante de uma época tumultuosa, que Lívio Abramo se fez xilógrafo hábil, consciencioso, exigente, dos mais penetrantes. [...] ele a colocou [...] a serviço da interpretação dos tipos populares, e essa foi uma das faces pelas quais a sua observação recriou a realidade dos costumes, da vida do povo, em contato direto com seus dramas e as suas necessidades". Seus modelos não são imaginados, mas observados no mercado de Itapecerica, no trecho antiquíssimo de $\mathrm{M}^{\prime}$ boy, nos ajuntamentos domingueiros de Santo Amaro". In FERRAZ, Geraldo. Lívio Abramo, p. 95.

24. FERRAZ, Geraldo. Depois de Tudo, p.107.

25. O Homem Livre, órgão do Partido Socialista,em São Paulo, durou aproximadamente 1 ano e combateu efusivamente o integralismo, esclarecendo a população a respeito das semelhanças entre integralismo, nazismo e o fascismo. Foi apreendido em 1937. FERRAZ, op.cit., p. 107.

26. CF. SIMONE, Eliana de Sá Porto de. Käthe Kollwitz.p. 188-189.

27. Arquivo da Fundação Bienal de São Paulo Wanda Svevo.

28. Rubens Ricupero foi Chefe da Divisão Cultural no período do General Emílio Garrastazu Médice (30 de outubro de 1969 a 15 de março de 1974). Entrevista concedida à pesquisadora, ag. 2009.

29. "Havia uma lista com nomes de vários artistas, mas encontramos um estratagema, que era dar a Medalha Rio Branco, uma condecoração costumeira no Itamaraty, a artistas que estivessem nessa lista. A partir daí, esses artistas deixavam de sofrer o veto dos militares, pois saiam dessa lista. Idem.

30. Na $1^{\mathrm{a}}$ Bienal de São Paulo, em 1951, Lívio Abramo fez parte do júri de premiação, indicado pelo presidente do MAM, Francisco Matarazzo. Na $4^{a}$ edição, em 1957, foi o $2^{\circ}$ secretário da diretoria executiva da Bienal, além de fazer parte do júri de seleção e de premiação. AMARANTE, Leonor. As bienais de São Paulo de 151 a 1987. 1989.

31. ESCOBAR, Ticio. Una interpretación de las artes visuales en El Paraguay, p. 347.

32. "El proyecto entero de la modernidad arrasta estigmas del tiempo de Stroessner. Es una modernidad enclaustrada e doblemente periférica: una modernidad oscura y desarticulada, crecida en forma dispareja por la corrupción que creaba opulentas oligarquías y por las tantas formas de opresión y marginalidad que renovaban puntualmente las viejas miserias". In ESCOBAR, Tício. El arte Fuera de Sí, pg.29.

33. GOOSSEN, Teresa. Olga Blinder, una biografia. p. 160.

34. ESCOBAR, Ticio. Entrevista concedida à pesquisadora em jul 2007.

35. ABRAMO, Lívio. Carta ao Ministro Sergio Barbosa Serra . Arquivo da Embaixada do Brasil no Paraguai. Assunção, 26 de dez de 1989, pg.4.

36. CF. HOBSBAWM, Eric J. Era dos Extremos, o breve século XX, 1914-1991.p. 8.

37. CF. Amaral, Aracy. Arte para quê ?p. 36.

38. O Grupo Santa Helena formou-se a partir dos anos 30 e reuniu imigrantes e filhos de imigrantes, muitos dos quais frequentavam o Liceu de Artes e Ofícios de São Paulo. Alguns possuíam outras atividades e direcionaram o aprendizado do Liceu para a pintura. Participaram 
do GSH: Volpi, Francisco Rebollo, Clóvis Graciano, Mario Zanini, Fulvio Pennacchi, Aldo Bonadei,Humberto Rosa, Manoel Martins, entre outros. Cf.,Amaral, Aracy, op.cit., p. 35.

39. A ODA, instituição criada na década de 30, pretendeu aglutinar todas as associações de artistas de São Paulo, como Grupo Santa Helena, OSIARTE e Sindicato dos Artistas Plásticos, e defender a absorção do trabalho dos artistas em várias frentes de trabalho na cidade, como decoradores de teatros, escultores, etc. Em 1939, Lívio Abramo teria sido o precursor da ideia de contratação dos artistas na decoração de edifícios públicos. CF. AMARAL, Aracy.op.cit., p. 136.

40. BREDARIOLLI, Rita. Das lembranças de Suzana Rodrigues. p. 177.

41. Revista Clima, de 1941 a 1944, ligada aos intelectuais da Universidade de São Paulo (Antonio Candido, Paulo Emilio, Lourival Gomes Machado, Ruy Coelho, Decio de Almeida Prado, e outros); Revista Anual do Salão de Maio, 1939, dirigida por Flávio de Carvalho com participação de Oswald de Andrade, Paulo Mendes de Almeida, Guilherme de Almeida, Luis Martins e outros; Revista Acadêmica, 1934-1935, com contribuições de Oswald de Andrade, Mário de Andrade, Caio Prado Junior, Rubem Braga; Bellas Artes, jornal mensal especializado em artes, dirigida por Quirino Campofiorito, de 1935 1940, no Rio de Janeiro; Revista Movimento, em 1935, com grande circulação das ideias políticas e culturais da época, pertencente ao Clube de Cultura Moderna, no Rio de Janeiro. Além das publicações citadas, começaram a circular a partir da década de 40/50 os cadernos especiais dos jornais: Letras e Artes, do Jornal A Manhã, no Rio de Janeiro, em 1946, e Suplemento Literário, do Jornal O Estado de São Paulo, a partir de 1956. CF. AMARAL, op.cit., p. 54-55; CANDIDO, Antonio. Conferência Centro Universitário Maria Antonia. São Paulo, set. 2010.

42. Com essa mostra o MAM SP abre oficialmente o museu ao público, estimulando a discussão da polêmica relação entre o figurativismo e o abstracionismo na arte. Organizada pelo belga Léon Degand, a mostra foi seguida de debate sobre a abstração no auditório da Biblioteca Nacional. CF. HOFFMANN, Ana Maria Pimenta, p. 47.

43. GONÇALVES, Lisbeth Rebollo. Sergio Milliet, Critico de Arte. p. 90.

44. CF. Rita BREDARIOLLI. Das lembranças de Suzana Rodrigues. ps.21e 22.

45. CF. GONÇALVES, Lisbeth Rebollo. Op.cit.p. 75-75.

46. ADAM, Fabíola. Entrevista da artista e ex-aluna de Livio Abramo à pesquisadora. Assunção, jul 2007.

47. CF. HERTZ, Mônica. A dimensão cultural nas relações internacionais: proposta teórico-metodológica. s 48. CF. ROUQUIÉ, Alain. O Estado militar na América Latina. 1984, p. 219. Alain Rouquié foi ministro da França e ex-embaixador no Brasil. É pesquisador da Fondation National des Sciences Politiques e do Institut dÈtudes Politiques de Paris. É autor de vários livros sobre a $\mathrm{AL}$, dentre os quais: Le mouvement Frondizi et le radicalisme argentin, 1967; Pouvoir militaire ET Societé politique em Republique Argentine, 1978, entre outros.

49. Ibidem.,p.219.

50. Ibidem.,p.219.

51. Ibidem.,p.219.

\section{RESUMOS}

O presente trabalho tem como eixo central a análise das ações culturais realizadas pelo artista Lívio Abramo (1903-1992) no Paraguai, para a aproximação das comunidades culturais do Brasil e 
daquele país, no contexto das orientações da diplomacia cultural brasileira, na segunda metade do século XX.Desde os anos 40,1 o Brasil manteve com o Paraguai acordos e convênios educacionais e técnicos, entretanto, essas ações só assumem uma dimensão artística a partir da chegada de Lívio Abramo naquele país, em 1962. Os programas culturais desenvolvidos pelo brasileiro junto à comunidade artística local, revelam uma herança adquirida de sua proximidade com os principais acontecimentos culturais da São Paulo pós 1922, de reafirmação da necessidade de uma modernização nas artes.

Depuis les années 40, le Brésil avait des accords et de conventions éducationnels et techniques avec le Paraguay, ce qu'était une partie d'un projet brésilien de s'aproximer de l'autre pays en question. Mais ces projets n'ont eu une dimension artistique qu'avec l'arrivée de Livio Abramo au Paraguay. Les projets culturels développés avec la communauté de ce pays montrent un héritage cultural que l'artiste a acquis au Brésil. Elle résulte de sa proximité avec les principaux événements qui ont eu lieu à São Paulo depuis 1922 et qui réaffirmaient la nécessité d'une modernisation dans les arts.

\section{ÍNDICE}

Palavras-chave: Abramo (Lívio), America Latina, ações culturais, herança do moderno paulista Mots-clés: Abramo (Lívio), Amérique latine, actions culturelles, patrimoine du São Paulo moderne

\section{AUTOR}

\section{MARGARIDA NEPOMUCENO}

Jornalista e Mestre em Integração da America Latina pela Universidade de São Paulo/Brasil 